\title{
The Influence of Governance Mechanism on Supply Chain Performance in Developing Economies: Insights from Ghana
}

\author{
Emmanuel Kwabena Anin ${ }^{1}$, Dominic Essuman ${ }^{2} \&$ Kwame Owusu Sarpong ${ }^{1}$ \\ ${ }^{1}$ Department of Procurement and Supply Chain Management, Kumasi Polytechnic, Ghana \\ ${ }^{2}$ Department of Information Systems and Decision Sciences, KNUST School of Business, Ghana \\ Correspondences: Emmanuel Kwabena Anin, Department of Procurement and Supply Chain Management, \\ Kumasi Polytechnic, Ghana. E-mail: premeracode5@yahoo.com
}

Received: January 10, 2016

doi:10.5539/ijbm.v11n4p252
Accepted: February 15, 2016

Online Published: March 15, 2016

URL: http://dx.doi.org/10.5539/ijbm.v11n4p252

\begin{abstract}
Drawing on the Transaction Cost Economics (TCE) and taking the perspective of a developing economy, the study examined the impacts of governance mechanisms (GM-formal control and social control) on supply chain (SC) performance (operational efficiency and service \& market performance). Data were collected using questionnaires from 152 firms operating in the most industrialized regions of Ghana. Structural equation modelling technique (using LISREL 8.5) was employed in estimating the study's model. The study finds significant positive associations between formal control and operational efficiency; and between social control and service \& market performance. The study also finds that within the research context, social control is antecedent of (adherence to) formal control; and that the effect of social control on operational efficiency is fully channelled via formal control. These findings imply that firms' ability to institute and implement GMs would present them opportunities to enhance the performance of their SCs. Theoretically, the results suggest the potential mediating role of formal control in the link between social control and SC performance; which means that having in place formal controls is necessary for firms in this part of the world (who mostly rely on social control) to better experience benefits arising out of social relationships.
\end{abstract}

Keywords: formal control, social control, transaction cost economics, supply chain performance, developing economies

\section{Introduction}

Developing economies play important role in the global supply chain (SC) particularly in terms of competitive material prices and reduced labour costs. This reflects in some leading firms being tempted to locate their manufacturing units in these economies. SC management (SCM) by its very nature depends on relationships and connections (Khalifa et al., 2008; Babbar et al., 2008). Firms in the developing economies are now participating in the global business networks through such relationship and connection with others across the globe to create wealth. However, their socio-cultural idiosyncrasies may influence the type of relationship governance mechanism they adopt. Whereas formally written contract agreements may be key in SC relationship management among firms in the developed economies, social contracts, which is mostly based on trust, is regarded as an important management tool in exchange relationship between SC members in the developing economies. In fact social contracts eliminate the need for formal contracts, which are costly to write and enforce. Thus social contracts ultimately, reduce transaction costs (Dyer, 1997; Hamisi, 2011).

Typically, SC is a network of organizations (and their functional units, processes, systems, infrastructure, materials, information, and services) whose efforts are directed at fulfilling a customer order (Chen \& Paulraj, 2004; Chopra \& Meindl, 2007; Baharanchi, 2009; Mentzer et al., 2001). When SC is appropriately managed, the outcome is one of enhanced performance (Chopra et al., 2007). As business competition shifts from between individual entities to SCs, adoption of SC practices could offer competitive advantage in the face of fierce competition on the global market (Christopher et al., 2006; Danese \& Romano, 2011). The integration of activities and processes among the members of the SC is usually referred to as SCM (Handfield \& Nichols, 2003). Theoretically, SCM focus on integrating products, processes, activities, systems, resources, as well as relationships from the point of origin (i.e. suppliers) to the point of consumption with the objective of maximizing value created for the network members (Pagell, 2004). The extent to which SC relationships drive 
performance largely depends on the governance mechanism (GM) adopted.

GM involves internal controls, checks and balances, audit review procedure and monitoring practices that organisations use as tools to manage co-operative relationship among stakeholders to improve performance. It includes set of measures organizations adopt as responses to conditions of uncertainty, dependence, and opportunism that exists in business relationships (Kock, 2008; Chartered Institute of Procurement and Supply, 2012; Macneil, 1978). Prior studies have suggested that GM influences inter-organisational relationships and the overall performances of SC (Ballou et al., 2008; Zhang et al., 2012; Bellouma et al., 2009). According to Huang et al. (2014) and Cai et al. (2009), GMs in SCs, which draw insights from the logic of transaction cost economics (Huang et al 2014), could be seen in two basic forms: formal control and social control. Social GM, (also relational control) (Huang et al., 2014; Cai et al., 2009), broadly refers to trust-based approach to governance (Martinez \& Jarillo, 1989; Dyer \& Singh, 1998) adopted to govern buyer-supplier relationship by creating social environment (Luo, 2007) for shared decision making (Saxton, 1997). It offers mechanism for conflict resolution through two way communication and joint problem solving approach (Kale et al., 2000). Thus, it is a mechanism through which SC interrelationships are regulated by a set of norms to restrict unacceptable behaviour of the parties (Heide \& John, 1992; Kim et al., 2010). Social governance adopted in this study draws insights from Macneil's (1980) argument that most exchange relationships rely heavily on social contracts, most frequently trust.

The second form of governance mechanism is formal control which consists of contractual agreement that prescribes formal rules of engagement to control and discourage opportunistic and conflicting behaviours through compliance in order to drive performance (Lumineau \& Malhotra, 2011; Macneil, 1978; Klein, et al., 1978). Formal control serves as a tool to address opportunism by its capacity to create mutually and legally agreed range of acceptable behaviours (Li et al., 2010; Liu et al., 2010). Again, contractual agreements do not only specify each party's roles, performance expectations, and dispute resolution mechanisms (Poppo \& Zenger, 2002) they also control the actions of the parties to ensure compliance and curb opportunistic behaviours of parties to a particular transaction to drive performance (Macneil 1978; Williamson, 1979; Roxenhalla \& Ghauri, 2004).

Social control appears more prevalent among small and medium scale enterprises in developing economies. These firms mostly manage their relations with their business partners on trust and loyalty (Hamisi, 2011). Taking Ghana as an example, it is common observation to find retailers placing orders with their suppliers without any formally written contracts. Among the large scale firms, particularly in the public sector where formal control governance appears to be mostly adopted, there have been instances of relationship issues arising from ineffective governance of contractual relations which have resulted in litigations and payment of judgment debt (Gakpo, 2014). SC operations involve several interlinking activities and transactions among various parties within the network. Such transactions among SC parties are naturally associated with one form of risk or the other. For example outsourcing, as operational function of SC, is characterized by quality, delivery and cost related risks, whose management requires development of long-term relationship among chain parties (Haung et al., 2014). Prior studies have indicated that in spite of the advantages of long-term relationships between SC parties, (suppliers and manufacturers, say), opportunistic behaviour and power conflicts among the parties could damage network collaboration and negatively affect performances (Claro et al., 2010; Zhang \& Keh, 2009; Prajogo \& Olhager, 2012; Zhang et al., 2012).

Empirically, there have been suggestions that both formal and social control mechanism complement each other in governing SC transactional relationships (Hernandez-Espallardo et al., 2010; Zheng et al., 2008; cited by Huang et al., 2014). However, others argue that social control mechanism can play substitute to the former in terms of managing SC relationship to improve performance (Das \& Teng, 2001; Li \& Zhang, 2010; Sengun \& Wasti, 2009). Huang et al. (2014) contend that this seemingly contradiction in extant literature obviously indicates uncertainty in respect of whether social control plays substitute to formal control or complement it in SC relationship governance. Also, studies on GM and SC performance, particularly in developing economies, with their cultural peculiarities appear rare. In the light of these, the need for further studies into the dynamics of governance mechanism and their effect on SC performance, particularly in the Ghanaian context is imperative. This study, drawing insights from transaction cost economics theory, makes a contribution to literature by its attempt to providing empirical validation to the dynamics of social control and formal control mechanisms and how they drive SC performance. Accordingly, the study seeks to address the following research questions: (1) what is the relationship between social control and formal control mechanism? (2) what is the relationship between social control mechanism and supply chain performance?; and (3) what is the relationship between formal control mechanism and supply chain performance? 
In the ensuing sections, we first briefly review exiting relevant literature and formulate the hypothetical model. We then describe the methodology employed in the study and the results obtained. Finally, we discuss our findings, draw conclusion and put forth limitations and recommendations of the study.

\section{Literature Review and Hypothesis Development}

\subsection{Transaction Cost Economics (TCE) and GM}

The tenet of TCE is that many of the transaction related costs are due to information gathering and gaining understanding (Coase, 1993; cited by Tate et al., 2014). Specifically, transaction related cost may include information seeking cost, bargaining or contract negotiation and contract monitoring and enforcing costs (Coase, 1937; cited by Tate et al., 2014). Information seeking cost has to do with the investment of time and resources associated with searching the alternatives (Hide \& Stump, 1995; cited by Tate et al., 2014). Bargaining or contract negotiation related cost include cost of negotiation, developing an agreement, and associated documentations while enforcement-related or monitoring cost results from activities that seeks to reduce risk of opportunism through contractual agreement. One of the concerns of TCE is opportunism which has to do with a deliberate decision and practices pursued to satisfy self-interest (Klein, 2006, cited Hernandez-Espallardo et al., 2010). Macneil (1978) and Williamson, (1979) also define opportunism as the tendency of pursuing self-interest when there is an opportunity to do so or maximizing self-interest in a way that undermines previously agreed or followed principles. Thus it is the desire and ability to take advantage of mistakes, errors and institutional weaknesses when relevant internal or external controls on people's behaviour are absent and one can make gains (Williamson, 1979; Williamson, 2008).

Roxenhalla (2004) opine that opportunism is characterized by compromise of integrity; that is, compromising or violating principles and upheld norms in society. It may involve deliberate distortion of information, doing less work than agreed or failing to fulfill formal obligations. Individuals pursue their self-interest in organisations where rules and sanctions (also referred to as control mechanisms) are lacking or weak (Huang et al., 2014; Foss \& Klein, 2009).

Seabright (2004) posits that where people have unequal access to information (information asymmetry), those who have the information can take advantage of the situation at the expense of the other party. In a typical organisational context, opportunistic behaviour finds its reflection in blatant abuse and exploitation of institutional weakness, deceit, distortion of information, corner cutting tactics in the pursuits of self-interest seeking, leading to poor organisational performances (Foss \& Klein, 2009; Huang et al., 2014). Given these, and having in place governance mechanisms (i.e. formal control and social control) would provide the organizations the opportunity and ability to effectively handle issues of opportunism and regulate other transaction-related behaviour of business partners.

\subsection{SC Performance}

SC performance relates to the value creation outcomes of the operations and practices within SCs. Over the years, extant literature has been unspecific in defining SC performance, and particularly, its dimensions. Some previous research have focused on delivery and flexibility (Huo, 2012; Prajogo \& Olhager, 2012), customer service (Vickery et al., 2003), efficiency (Danese \& Romano, 2011; Prajogo \& Olhager, 2012), and service performance (i.e. delivery and support) (Droge et al., 2012), among others. While some study focuses on one of these performance dimensions, others consider more than one. In this study, we defined and measured SC performance in terms of operational efficiency and service \& market performance.

\subsection{Social Control and Formal Control}

The logic of TCE maintains that contract could be used to address the problem of opportunism. However, it is not practicable to provide contractual arrangement with exhaustive description of rights and obligations to meet every eventuality (Coltman et al., 2009; cited by Huang et al., 2014). Thus even though formal control is needed to align the interest of transacting parties and to discourage opportunism, over reliance on it could be detrimental to performance outcomes arising from monitoring cost and dilution of autonomy. Indeed in its strictest sense of application, contract could result in low flexibility and trust.

On the other hand social control mechanism promotes flexibility, trust building, and commitment among transacting parties. Huang et al. (2014) argue that the potential of social control in creating social norms, inspiring commitment and building trust among parties of SC discourages opportunism. Given this, where trust and commitment is higher among channel members, the tendency for them to honour their contractual obligations would be higher. Therefore, we argue that compliance or adherence to formal agreements, regulations, and procedure, could be achieved through social controls. 
Taking the case of developing economies, for example, where most industries are dominated by micro, small and medium scale businesses, reliance on social control is high as it provides avenues for organizations to get their business partners complying with contractual arrangement and honouring relationship obligations. These firms mostly manage their relations with their business partners and execute transactions based on trust and loyalty. Thus, where social control is insufficient, adherence to formal control mechanism could be poor. Against this background, we posit that:

$H_{1}$ : For firms in developing economies, social control is positively associated with adherence to formal control.

\subsection{Social Control and SC Performance}

Social control concerns the adoption of set of norms, social network and trust building to govern SC interrelationships among transacting parties to restrict unacceptable behaviours of the parties (Heide \& John, 1992; Williamson, 1979). Sociologists have demonstrated that trust and other forms of social relationships play crucial role in economic transactions (Zheng et al., 2008). Social control has been recently considered as useful tool that can be used to inhibit opportunism, enhance cooperation in buyer -supplier exchanges (Kim et al., 2010; Liu et al., 2010), and reduce transaction cost in terms of monitoring and negotiations (Zhang \& Keh,, 2009; Cai et al., 2009).

Social control assumes that a partner would, out of trust, commitment and loyalty, perform actions that results in positive outcomes (Yu \& Liao, 2008; cited Haung et al., 2014). The existence of trust between two partners, which characterizes social control mechanism, helps facilitate joint planning and problem solving (Claro et al., 2010), and create stable and committed relationships. Thus, the flexible nature of social control mechanisms makes it easy for the manufacturing firm and the supplier, say, to jointly enhance their exchange relationships beyond the specifications of the contracts, improve communication, information sharing, respond to environment uncertainty and to deal with unpredicted problems (Paulraj et al., 2008; Luo, 2007). From the lens of TCE, social control establishes non-legal sanctions and relational norms that encourage commitments among the transacting parties and thereby improves performance outcomes. Thus social control has the potential to reduce transaction cost, increase collaboration and improve performance (Haung et al., 2014). In line with these, we argue that:

$\mathrm{H}_{2}$ : Social control is positively associated with $\mathrm{SC}$ performance in terms of operational efficiency $\left(\mathrm{H}_{2 a}\right)$ and service \& market performance $\left(H_{2 b}\right)$.

\subsection{Formal Control and SC Performance}

Formal control involves the use of contractual agreements in the management of relationships between SC partners. Specifically it sets out legal rules and regulations upon which contractual relationships are governed (Huang et al., 2014). According to TCE theory, human beings naturally behave economically and that there is the natural tendency to be opportunistic. The argument is made that investment could be exploited by business partners' opportunistic behaviours such as lying, cheating or violation of agreement. In view of this, certain measures are required to protect transaction specific investment (Randfleisch \& Heide, 1997; cited Cai et al., 2009). TCE further asserts that formal control sets out contractual rules that check and control the behaviour of opportunistic partner to reduce opportunism, protect specific investments and increase performance (Dan \& Rahman, 2010; Liu et al., 2010).

Thus, the adoption of formal control provides legal protection to transacting parties and deals with the conflicting interest and opportunism for improved performance and mutual benefits. It ensures that rewards and sanctions are matched to partners' behaviour which in the long - run, reduces opportunism (Cai et al., 2009; Huang et al., 2014). Thus, formal agreement is one of the mechanisms designed to reduce the risk of opportunistic behaviours of transacting partners. In this sense, the use of formal control in governing relationships between SC partners drives co-operation and improved performance (Huang et al., 2014; Tate et al., 2014; Huo, 2012). Drawing insight from the argument of TCE, we propose that:

$H_{3}$ : Formal control is positively associated with $S C$ performance; in terms of operational efficiency $\left(H_{3 a}\right)$ and service \& market performance $\left(H_{3 b}\right)$.

The proposed theoretical framework of the study is given in Figure 1. 


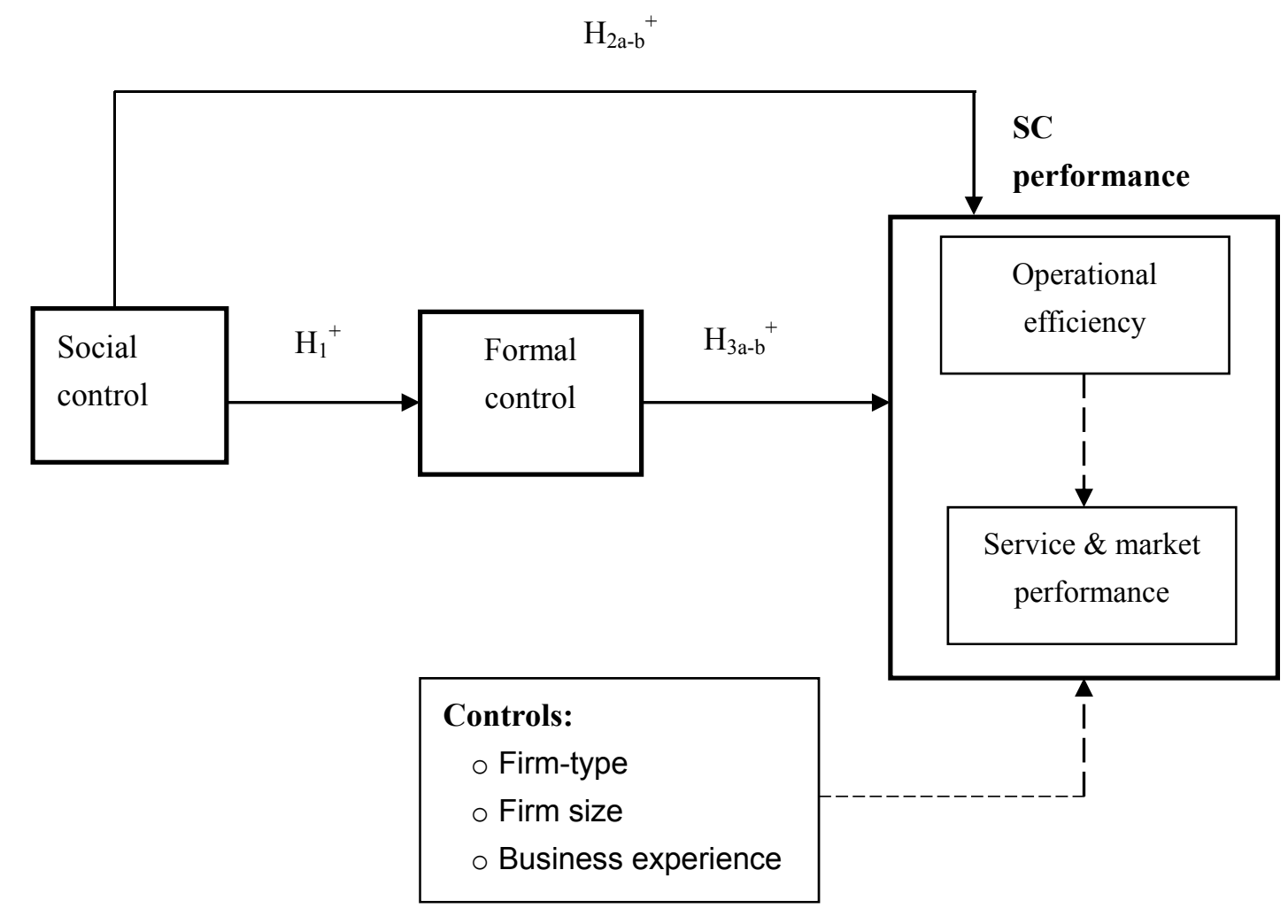

- - - - - $\longrightarrow$ Non-hypothesized paths

Figure 1 Proposed theoretical framework

\section{Methods and Results}

\subsection{Study Setting and Design}

To address the research questions, cross-sectional data were collected from firms (refer to table 1 for firm categories) operating in four key political and economic regions of Ghana, i.e. Greater Accra, Ashanti, Eastern, and Western. Firms from these regions cover wider spectrum of SC operations in Ghana and therefore the outcome would be a fair representation of the Ghanaian situation. Out of the 192 firms contacted, 59, 41, 30, and 24 firms in these parts of the country respectively participated in the study. Owing to incompleteness of data, responses from 2 firms were rejected. Responses from 152 (79.17\%) were thus considered effective for the study. The data collection spanned from March 2015 to July 2015. The firms were contacted in person by the researchers. In each case, the data collection instrument was delivered and collected later. In line with previous research, individuals (refer to table 1) considered as having adequate experience (i.e. years of service as well as insights on managerial issues) in their firms' operations and business environment were asked to provide responses for the study.

\subsection{Measures and Questionnaire Development}

To enhance the quality of the study, most of the items used in measuring the study's constructs were adapted from previous literature. The items for formal and social control were adapted from Huang et al. (2014) while those for SC performance (i.e. operational efficiency and service \& market performance) were adapted from Ryu et al. (2009) and Hernandez-Espallardo et al. (2010). A 7-point scale ranging from "1=strongly disagree" through " $4=$ neither agree nor disagree" to " $7=$ strongly agree" was used to measure all constructs. In addition, the study captured data on firm type (i.e. service $=1$; others $=0$ ), business experience (i.e. number of years in the industry) as well as firm size (i.e. number of employees). In line with previous knowledge, the potential effects of these variables on firm performance were controlled for in our study. The service firms were used as a reference point in our analysis given that they represented the greatest proportion of data (in terms of firm category) collected 
for the study.

\section{Results}

\subsection{Respondent and Firm Profile Information}

Table 1. Respondent and firm profile information

\begin{tabular}{llll}
\hline & & $n$ & $\%$ \\
\hline \multirow{2}{*}{ Gender } & Male & 100 & $65.8 \%$ \\
& Female & 52 & $34.2 \%$ \\
& HND & 46 & $30.3 \%$ \\
1st Degree & 2nd Degree & 86 & $56.6 \%$ \\
& PhD & 14 & $9.2 \%$ \\
& Others & 4 & $2.6 \%$ \\
& SC/Logistics manager/officer & 2 & $1.3 \%$ \\
& CEO/Vice & 29 & $19.1 \%$ \\
Position & MD/General manager & & $9.9 \%$ \\
& Operations Manager & & $41.4 \%$ \\
& Others & 63 & $7.2 \%$ \\
Manufacturing & & 11 & $22.4 \%$ \\
Firm type & Mining & 34 & $23.0 \%$ \\
& Logistics/distribution & 35 & $14.5 \%$ \\
& Service & 22 & $19.1 \%$ \\
\hline Oears held position & & 29 & $42.1 \%$ \\
Business experience (years of operation) & & 64 & $1.3 \%$ \\
\hline Firm size (number of employees) & & 2 & Std. Dev. \\
\hline
\end{tabular}

\subsection{Validity and Reliability}

Confirmatory factor analysis (CFA - using covariance matrix as the input and maximum likelihood as the estimation method) was used to validate all measures while Cronbach Alpha (CA) was used to assess their reliability. The results of these analyses are shown in Table 2. All CA values obtained were above the recommended threshold of .70 (Bagozzi \& Yi, 2012) and thus suggests good internal consistency in the measures (Field, 2009). The CFA model fit results after necessary purifications: Chi-square (degree of freedom) $\left[\chi^{2}(\mathrm{DF})\right]=$ $50.95(48)$; normed Chi-square $\left(\chi^{2} / \mathrm{DF}\right)=1.061$; root mean square error of approximation $(\mathrm{RMSEA})=.020$; non-normed fit index $(\mathrm{NNFI})=.989$; comparative fit index $(\mathrm{CFI})=.992$; and standardized mean square residual $(\mathrm{SRMR})=.043$; obtained and the positive and significant (at $1 \%$ ) loadings indicate satisfactory convergent validity. Also, the results show that composite reliability and discriminant validity of the variables were acceptable, given that the indices obtained exceed the minimum cut-off criteria of .60 and .50 respectively (Bagozzi \& Yi, 2012). The average variances extracted were also greater than the shared variances between constructs (refer to Table 3), and thus signifying satisfactory discriminant validity (Fornell \& Larcker, 198; cited by Boso et al., 2013). 
Table 2. Measurement model results

\begin{tabular}{|c|c|c|c|c|}
\hline Constructs/measures & $\begin{array}{l}\text { Standardized } \\
\text { loadings }\end{array}$ & Errors & t-values & $\begin{array}{l}\text { R } \\
\text { square }\end{array}$ \\
\hline \multicolumn{5}{|l|}{ Formal control $(C A=.787 ; C R=.795 ; A V E=.567)$} \\
\hline FC1: A set of rules created for my firm and its partners & $.862^{\dagger}$ & .257 & Fixed & .743 \\
\hline FC2: Specific, well-detailed agreement with our business partners & .737 & .457 & 8.08 & .543 \\
\hline $\begin{array}{l}\text { FC3: Formal agreement that details the obligations of both our } \\
\text { firm and business partners }\end{array}$ & .645 & .585 & 7.32 & .415 \\
\hline \multicolumn{5}{|l|}{ Social control $(C A=.852 ; C R=.853 ; A V E=.660)$} \\
\hline SC2: Social events with our business partners & .812 & .341 & 10.17 & .659 \\
\hline SC3: Joint workshop with our partners & .829 & .313 & Fixed & .687 \\
\hline SC4: Regular supplier conferences & .795 & .367 & 10.02 & .633 \\
\hline \multicolumn{5}{|l|}{ Operational efficiency $(C A=.766 ; C R=.779 ; A V E=.547)$} \\
\hline OE1: Decrease operating costs such as material and labour costs & .562 & .684 & 6.51 & .316 \\
\hline OE2: Organise its production activities more efficiently & .844 & .287 & Fixed & .713 \\
\hline OE3: Improve productivity and make good use of resources & .783 & .386 & 8.61 & .614 \\
\hline \multicolumn{5}{|l|}{$\begin{array}{l}\text { Service \& market performance }(C A=.744 ; C R=.753 \text {; } \\
A V E=.506)\end{array}$} \\
\hline SMP2: Be more competitive in satisfying customers & .605 & .634 & 6.63 & .366 \\
\hline SMP3: Compete more favourably in the marketplace & .779 & .392 & Fixed & .608 \\
\hline SMP4: Increase revenue or sales & .738 & .455 & 7.80 & .545 \\
\hline
\end{tabular}

Notes.

1. $\mathrm{CA}=\mathrm{Cronbach}$ Alpha, $\mathrm{CR}=$ Composite Reliability, $\mathrm{AVE}=$ Average Variance Extracted

2. ${ }^{\dagger}$ Loadings significant at $1 \%$

Table 3. Inter-construct correlations and descriptive statistics

\begin{tabular}{lcccccccc}
\hline Variables & FC & SC & OE & SMP & Min & Max & Mean & Std. Dev. \\
\hline Formal control (FC) & & .119 & .080 & .108 & 3.00 & 7.00 & 5.70 & .757 \\
Social control (SC) & $.345^{* *}$ & & .023 & .114 & 1.00 & 7.00 & 5.25 & .930 \\
Operational efficiency (OE) & $.282^{* *}$ & .153 & & .265 & 1.67 & 6.67 & 5.37 & .928 \\
Service \& market performance (SMP) & $.329^{* *}$ & $.338^{* *}$ & $.515^{* *}$ & & 1.67 & 7.00 & 5.83 & .911 \\
\hline
\end{tabular}

Notes.

1. Values above the principal diagonal represent shared variances between constructs while those beneath it represent correlation between constructs.

2. $* *$ Coefficients are significant at $5 \%$ (2-tailed test).

\subsection{Common Method Bias (CMB) Assessment}

Given the potential source of bias in employing the method of data collection used in this study, it became necessary to assess the presence of $\mathrm{CMB}$ and the extent of its threats to the quality of the study. Following existing techniques (see for e.g., Boso et al., 2013), we tested for three competing models. In model 1 (method-only), all items were loaded on a single latent factor: $\chi^{2}(\mathrm{DF})=548.95(90) ; \chi^{2} / \mathrm{DF}=6.099$; $\mathrm{RMSEA}=.184$; NNFI $=.396 ; \mathrm{CFI}=.482$; and $\mathrm{SRMR}=.131$; model 2 (trait-only) had items loaded on their respective constructs: $\chi^{2}(\mathrm{DF})=183.59(84) ; \chi^{2} / \mathrm{DF}=2.186 ; \mathrm{RMSEA}=.089 ; \mathrm{NNFI}=.835 ; \mathrm{CFI}=.868 ;$ and $\mathrm{SRMR}=.079$; while model 3 (method and trait) included a common factor linking all items in model $2: \chi^{2}(\mathrm{DF})=$ $150.81(65) ; \chi^{2} / \mathrm{DF}=2.320 ; \mathrm{RMSEA}=.094 ; \mathrm{NNFI}=.800 ; \mathrm{CFI}=.876$; and $\mathrm{SRMR}=.076$. By comparisons, it can be seen that model 2 and 3 had far better model fit indices than model 1, and that model 3 was not substantially better than model 2; which shows that CMB does not sufficiently describe our data. Accordingly, we did not consider CMB as a major problem to our study.

\subsection{Structural Model Analysis}

The results of our structural equation model (SEM) are presented in Table 4. Model 1 had the two outcome 
variables predicted by firm type, firm size, and business experience; with all other paths constrained to zero. This Model did not yield satisfactory model fit indices: $\chi^{2}(\mathrm{DF})=188.75(57) ; \mathrm{X}^{2} / \mathrm{DF}=3.311 ; \mathrm{RMSEA}=.124$; $\mathrm{NNFI}=.694 ; \mathrm{CFI}=.776$; and $\mathrm{SRMR}=.173$. When our proposed model was estimated (i.e. Model $2-$ all paths were freely estimated), an acceptable model fit indices were obtained: $\chi^{2}(\mathrm{DF})=79.19(51) ; \chi^{2} / \mathrm{DF}=1.553$; $\mathrm{RMSEA}=.061 ; \mathrm{NNFI}=.918 ; \mathrm{CFI}=.947$; and $\mathrm{SRMR}=.069$. Based on the results in Model 2, the study's hypotheses are evaluated as follows:

$H_{l}$ stated that for firms in developing economies, social control is positively associated with formal control. This hypothesis is supported, given a significant parameter estimate $(\beta=.38 ; \mathrm{t}=4.44)$.

$\mathrm{H}_{2}$ stated that social control is positively associated with SC performance; in terms of operational efficiency $\left(H_{2 a}\right)$ and service \& market performance $\left(H_{2 b}\right)$. The results of the study partially support this hypothesis; given the following results social control $\rightarrow$ operational efficiency $(\beta=.06 ; \mathrm{t}=.63)$ and formal control $\rightarrow$ service $\&$ market performance $(\beta=.26 ; \mathrm{t}=3.12)$.

$\mathrm{H}_{3}$ argued that formal control is positively associated with SC performance; in terms of operational efficiency $\left(H_{3 a}\right)$ and service \& market performance $\left(H_{3 b}\right)$. The results of the study partially support this hypothesis; given the following results social control $\rightarrow$ operational efficiency $(\beta=.33 ; \mathrm{t}=3.12)$ and formal control $\rightarrow$ service $\&$ market performance $(\beta=.13 ; \mathrm{t}=1.29)$.

Table 4. Structural model results

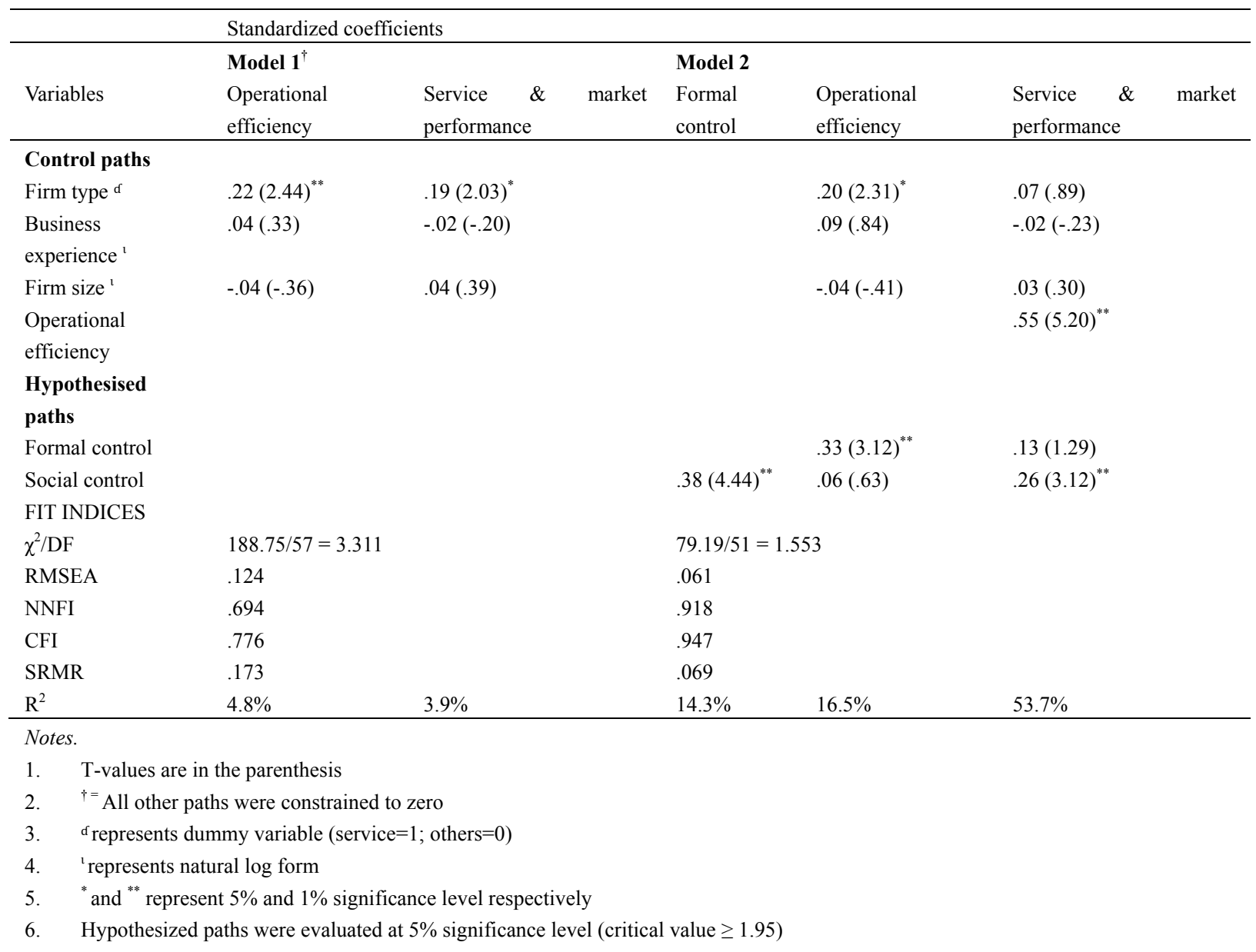

\section{Discussions of Findings: Contributions and Implications}

Focusing on the business context of Ghana, the study was set to examine whether firms in developing economies accrue performance benefits from governance mechanism instituted in their supply chains. In line with literature (Cai et al., 2009; Huang et al., 2014), two basic governance mechanism (social control and formal control) were examined in the SCs of firms contacted for the study. Drawing insights from the transaction cost economics 
(TCE), we model the effects of social control and formal control on two supply chain performance dimensions: operational efficiency and service \& market performance, and also, a path from social control to formal control mechanism. The findings of the study raise the following implications for researchers and managers:

First, the study provides support to theory underpinning this study. The results obtained indicate that having in place formal control and social control are necessary for enhancing the performance of supply chains, as these governance mechanisms enable the focal firm to manage opportunistic behaviour (such as cheating, lying, deliberate attempts not to honour promises) of its network members (Dan \& Rahman, 2010; Liu et al., 2010; Haung et al., 2014). It must be noted that, human beings, and for that matter organizations, are naturally opportunistic, hence, the absence or weakness of these governance mechanisms is a recipe for organisational and supply chain failure. Instituting and adhering to these governance mechanisms allows firms, directly or indirectly, to gain compliance, trust, and commitment from their business partners in the supply chain.

Secondly, the study argued for, and finds support that social control is an antecedent of formal control. This insight is a much reflection of the business context in which the study was carried out. Generally, most businesses in developing economies (like Ghana) are not well-developed in terms of structure and formal governance. As such, management, employees, and channel members' understanding on contractual agreements is somehow low, and for that matter, adhering to formal controls would require informal relationship building (i.e. social control) which presents firms the opportunity to understand each other over time, build trust, and gain commitment (Lusch \& Brown, 2010; Yu \& Liao, 2008, Haung et al., 2014). Also, within this business context, when emphasis on formal control is so high, people as well as organizations find ways to subvert it. Getting them to follow regulations and rules means that management must develop informal relationship, build structures and programmes (like social gatherings, networking, informal visits, etc.). In this business environment, sustained compliance is not effectively gained through 'force', but rather, willingness and readiness emerging out of the informal ties between individuals/organizations. Thus reinforcing Dyer's ( 1997) cited Hamisi (2011) assertion that social ties, which are based on trust and loyalty, reduce the need for rigid formal contracts, which are costly to write, monitor, and enforce. This ultimately reduces transaction costs.

In addition, the study demonstrates that, although both formal control and social control positively affect supply chain performance, the impact level of each of these governance mechanisms differ significantly on specific performance dimensions of the supply chain. We find that, while formal control has significant positive association with operational efficiency, social control does not. On the other hand, we find that social control (rather than formal control) presents firms greater opportunity to excel in delivering products to the market and become more competitive. This is an additional contribution to knowledge that this study offers. Generally, formal control approach to institutional governance and management of relationships in the supply chain is built on 'rigidities', regulations, and procedures (Poppo \& Zenger, 2002; Huang et al., 2014). Hence, the tendency for its adherence resulting in optimized supply chain efficiency is more likely to occur, which this study's results reveal. Supply chain efficiency as manifested in the areas of decreased operating costs, optimum utilization of resources, for example, is more likely to be experienced when due diligence is paid to operational procedures and regulations, which formal control specifies.

Also, today's business environment is largely characterized by time-based competition, increasing demanding nature of channel members (particularly, those in the down-stream portion of the supply chain where channel power is shifting towards the retailers/consumers' end), and shortening life cycle of products, paying greater attention to 'rules' could be detrimental to the performance of the supply chain. At times, as the situation would present itself and permit, in order to meet the needs of the market better than competitors, it would require that firms adopt other structures that allow flexibility and swiftness in delivering products; in which case social control does better than formal control (Huang et al., 2014). Taking the business context of Ghana for example, out of trust resulting from social relationships, a retailer who has run out of stock would normally make just a phone call for replenishment, and the supplier(s) would not 'think-twice' and go on to deliver it.

By implication, the study's results clearly indicate that, management's decision to pursue either social control or formal control should be guided by specific expectations. For those who want to enhance their service \& market performance should lean more on social control while those wanting to optimize operational efficiency in their supply chains should resort more to formal control. Notwithstanding this, it should be noted that (per the study's results), since both efficiency and service \& market performance are sub-dimensions of a broader construct (i.e. supply chain performance) paying attention to improving only one would not yield an optimum benefit for the supply chain. And therefore, both social control and formal control should be pursued by firms in a shrewd fashion. 
Fourthly, the study reveals that the effects social control on supply chain performance is contingent upon the formal control in two ways. At one hand, the results indicate that formal control fully transmits the effect of social control on operational efficiency dimensions of supply chain performance while it only partially carries the effect of social control on service \& market performance. These results further signify that resorting to only social control (although most pronounced in the study's context) may not be the best option for firms, as in some cases, its (i.e. social control) potential benefits would first enhance (adherence to) formal control, before the organization/supply chain would benefit in terms of (either) efficiency and (or) service \& market performance. This implies that, the supply chain performance benefit of social control, in some instances, would not be experienced where or when there is lack of or non-existence of formal control. Relatedly, the study finds that, although formal control does not have significant direct (positive) effect on service \& market performance dimension of the supply chain, its effect is carried through operational efficiency. This finding still reinforces our earlier point raised on why firms in this business context should also focus on developing formal control mechanisms in their supply chains.

\section{Conclusion}

The findings of this study reinforce extant literature claims on the benefits of governance mechanisms to organizations and supply chains. The study specifically finds that social control is more likely to enhance service \& market performance while formal control is more likely to do well in enhancing operational efficiency within supply chains. In as much as the study reports that formal and social controls have distinct positive impacts on supply chain performance, the former is also found to be a contingent factor for the success of the latter. And thus, firms' ability to institute formal control mechanism would serve as a conduit to transmit the positive effects of social control on supply chain performance.

Also the study advanced and found adequate support that without adequate presence of social control mechanisms, firms within supply chains, particularly, in developing economies, would find it challenging to pursue formal control. In a nutshell, based on the study's findings, we can say that firms or supply chain efforts to institute and adhere to governance mechanisms would not be a time or resource wasting.

\subsection{Limitation and Suggestions for Future Research}

Despite the insights gained from the study, there are some limitations though. In the first place, the sample population and the sampling technique employed present limitations to this present study. Although some of the study's arguments and discussions were made in reference to developing economies, the study was contextualized in Ghana. Not only this, but also, we were not able to include firms operating in the other six political/administrative regions of Ghana. We only focused on firms operating in the most industrialized regions of Ghana even though Ghana as a whole has unique human and organizational behavioural characteristics when it comes to following regulations, gaining compliance, and building relationships.

Also, though we point out the tendency of formal control mediating the link between social control and supply chain performance, this present study did not focus on assessing the mediating role of formal control, hence we did not perform further tests to assess the robustness of this finding. Same can be said of the identified mediating role of operational efficiency in the link between focal and service \& market performance. We therefore suggest that further research should be carried out on these issues.

\section{References}

Bagozzi, P. R., \& Yi, Y. (2012). Specification, evaluation, and interpretation of structural equation models. Academy of Marketing Science, 40, 8-34. http://dx.doi.org/10.1007/s11747-011-0278-x

Baharanchi, S. R. H. (2009). Investigation of the Impact of Supply Chain Integration on Product Innovation and Quality Transaction. Industrial Engineering, 16(1), 81-89.

Bailey, K., \& Francis, M. (2007). Managing information flows for improved value chain performance. International Journal of Production Economics, 111(1), 2-12. http://dx.doi.org/10.1016/j.ijpe.2006.11.017

Ballou, R. L., Gilbert, S. M., \& Mukherjee, A. (2000). New managerial challenges from supply chain opportunities: Selling and sales management in action: The use of insight coaching to improve relationship selling. Industrial Marketing Management, 29(12), 7-18.

Bellouma, M., Bennaceur, S., \& Omri, A. (2009). The impact of lending relationship on risk premium and credit availability: Evidence from Tunisia. Afro-Asian Journal of Finance and Accounting, 1(3), 235-250.

Boso, N., Story, V. M., \& Cadogan, J. W. (2013). Entrepreneurial orientation, market orientation, network ties, and performance: Study of entrepreneurial firms in a developing economy. Journal of Business Venturing, 
(28), 78-727. http://dx.doi.org/10.1016/j.jbusvent.2013.04.001

Cai, S., Yang, Z., \& Hu, Z. (2009). Exploring the governance mechanisms of quasi-integration in buyer-supplier relationships. Journal of Business Research, (62), 660-666. http://dx.doi.org/10.1016/j.jbusres.2008.02.004.

Chen, I. J., \& Paulraj, A. (2004). Towards a theory of supply chain management: The constructs and $\begin{array}{llll}\text { measurements. Journal of } & \text { Operations }\end{array}$ http://dx.doi.org/10.1016/j.jom.2003.12.007

Cheng, J. H., Yeh, C. H., \& Tu, C. W. (2008). Trust and knowledge sharing in green supply chains. Supply chain management: An international Journal, 11(4), 283-295.

Chopra, S., \& Meindl, P. (2007). Supply Chain Management, Strategy, Planning \& Operation (3rd ed.). Upper Saddle. New Jersey: Pearson Education.

Christopher, M., Peck, H., \& Towill, D. (2006). A Taxonomy for selecting globa supplychain strategies. International Jounal of Logistics Management, 17(2), 27-87.

Claro, D. P., \& Claro, P. B. (2010). Collaborative buyer-supplier relationships and downstream information in marketing channels. Industrial Marketing Management, 39(2), 221-228. http://dx.doi.org/10.1016/j.indmarman.2009.03.009

Danese, P., \& Romano, P. (2011). Supply Chain integration and efficiency performance: A study on the interactions between customer and supplier integration. Supply Chain Management: An International Journal, 16(4), 220-230. http://dx.doi.org/10.1108/13598541111139044

Das, \& Teng. (2001). Trust, Control, and Risk in Strategic Alliances: An Integrated Framework. Organization Studies, 22(2), 251-283. http://dx.doi.org/10.1177/0170840601222004

Droge, C., Vickery, K. S., \& Jacobs, A. M. (2012). Does supply chain integration mediate the relationships between product/process strategy and service performance? An empirical study. Int. J. Production Economics, 137, 250-262. http://dx.doi.org/10.1010/j.ijpe.2012.02.005

Dyer, J. H., \& Singh, H. (1998). The relational view: Cooperative strategy and sources of interorganizational competitive advantage. Academy of Management Review, 23(4), 660-679. http://www.jstor.org/stable/259056

Field, A. (2009). Discovering statistics using SPSS (3rd ed.). SAGE Publications Inc. California: Thousand Oaks.

Foss, N. J., \& Klein, P. G. (2009). Austrian Economics and The Transaction Cost. Libertarian Papers, 1(39).

Gakpo, J. O. (2014). Ghana's Judgement Debt. Retrieved from http://www.ghanaweb.com/GhanaHomePage/NewsArchive/Ghana-battling-over-536-judgment-debt-cases395039

Hamisi, S. (2011). Challenges and opportunities of Tanzanian SMEs in adapting supply chain management. African Journal of Business Management, 5(4), 1266-1276.

Handfield, R. B., \& Nichols, E. L. (2003). Key issues in global supply base management. Industrial Marketing Management, 33(1), 29-35. http://dx.doi.org/10.1016/j.indmarman.2003.08.007

Heide J., \& John, G. (1992). Do norms matter in marketing relationships? Journal of Marketing, 56, 32-44.

Heide, J. B. (1994). Interorganizational Governance in Marketing Channels. Journal of Marketing, 58(1), 71-85.

Heide, J. B., \& John, G. (1990), Alliances in Industrial Purchasing: The Determinants of Joint Action in Buyer-Supplier Relationships. Journal of Marketing Research, 27(1), 24-36.

Hernandez-Espallardo, M., Rodríguez-Orejuela, A., \& Sánchez-Pérez, M. (2010). Inter-organizational governance, learning and performance in supply chains. Supply Chain Management: An International Journal, 15(2), 101-114. http://dx.doi.org/10.1108/13598541011029714

Huang, M., Cheng, H., \& Tseng, C. (2014). Reexamining the direct and the interactive effects of governance mechanisms upon buyer-supplier cooperative performance. Industrial Marketing Management, 43(1), 704-716. http://dx.doi.org/10.1016/j.indmarman.2014.02.001

Huo, B. (2012). The impact of supply chain integration on company performance: An organizational capability perspective. Supply Chain Management: An International Journal, 17, 596-610. http://dx.doi.org/10.1108/13598541211269210 
Kale, P., Singh, H., \& Perlmutter, H. (2000).Learning and protection of proprietary assets in strategic alliances: Building relational capital. Strategic Management Journal, 21(3), 217-237. http://dx.doi.org/10.1002/(SICI)1097-0266(200003)21:3

Khalifa, N., White, A., \& Elsayed, A. (2008). Cybernetic Intelligent Systems, CIS 2008. 7th IEEE International Conference.

Kim, K. K., Park, S., Ryoo, S. Y., \& Park, S. K. (2010). Inter-organizational cooperation in buyer-supplier relationships: Both perspectives. Journal of Business Research, 63(8), 863-869. http://dx.doi.org/10.1016/j.jbusres.2009.04.028

Klein, B., Robert, G. C., \& Armen, A. A. (1978). Vertical Integration, Appropriable Rents, and the Competitive Contracting Process. The Journal of Law \& Economics, 21(2), 297-326. http://dx.doi.org/10.1086/466922

Kock, N. (2008). Encyclopedia of E-Collaboration (pp. 1-750). Hershey, PA: IGI Global. http://dx.doi.org/10.4018/978-1-59904-000-4.

Lambert, D. M. S., James, R., \& Elram, L. (2006). Fundamentals of Logistics. International Edition, Singapore: McGraw Hill.

Li, Y., Xie, E., \& Peng, M. W. (2010). Formal control and social control in domestic and international buyersupplier relationships. Journal of Operations Management, 28(4), 333-344. http://dx.doi.org/10.1016/j.jom.2009.11.008

Liu, Y., Yuan, L., \& Zhang, L. (2010). Control mechanisms across a buyer-supplier relationship quality matrix. Journal of Business Research, 63, 3-12. http://dx.doi.org/10.1016/j.jbusres.2009.01.005

Lumineau, F., \& Malhotra, D. (2011). Shadow of the contract: How contract structure shapes interfirm dispute resolution. Strategic Management Journal, 32(5), 532-555. http://dx.doi.org/10.1002/smj.890

Lumineau, F., James, E., \& Henderson, E. J. (2012). The influence of relational experience and contractual governance on the negotiation strategy in buyer-supplier disputes. Journal of Operations Management, 30(5), 382-395. http://dx.doi.org/10.1016/j.jom.2012.03.005

Luo, Y. (2007). A co-operation perspective of global competition. Journal of World Business, 42(2), 129-147.

Macneil, IR. (1978). Contracts: adjustment of long-term economic relations under classical, neoclassical and relational contract law. Northwestern University Law Review, 72, 854-905.

Macneil, IR. (1980). The New Social Contract: An Inquiry into Modern Contractual Relations. Yale University Press: New Haven, CT.

Mentzer, J. T., DeWitt, W., Keebler, J. S., Soonhong, M., Nancy, W., \& Smith, D. C. (2001). Supply chain management. Journal of Business Logistics, 22(2), 1-25.

Pagell, M. (2004). Understanding the factors that enable and inhibit the integration of operations, purchasing and logistics. Journal of Operations Management, 22(5), 459-87. http://dx.doi.org/10.1016/j.jom.2004.05.008

Paulraj, A., Lado, A. A., \& Chen, I. J. (2008). Inter-organizational communication as a relational competency: Antecedents and performance outcomes in collaborative buyer-supplier relationships. Journal of Operations Management, 26(1), 45-64. http://dx.doi.org/10.12691/ijefm-2-2-2

Poppo, L., \& Zenger, T. (2002). Do formal contracts and relational governance function as substitutes or complements? Strategic Management Journal, 23, 707-725. http://dx.doi.org/10.1002/smj.249

Prajogo D., \& Olhager, J. (2012). Supply chain integration and performance: The effects of long-term relationships, information technology and sharing, and logistics integration. International Journal of Production Economics, 135(1), 514-522. http://dx.doi.org/10.1016/j.ijpe.2011.09.001

Roxenhalla, T., \& Ghauri, P. (2004). Use of the written contract in long-lasting business relationships. Journal of Industrial Marketing Management, 33, 261-268. http://dx.doi.org/10.1016/j.indmarman.2003.10.015

Ryu, I., So, S., \& Koo, C. (2009). The role of partnership in supply chain performance. Industrial Management \& Data Systems, 109(4), 496-514. http://dx.doi.org/10.1108/02635570910948632

Saxton T. (1997). The effects of partner and relationship characteristics on alliance outcomes. Academy of Management Journal, 40, 443-461.

Sengun, A. E., \& Wasti, S. N. (2009). Revisiting Trust and Control: Effects on Perceived Relationship Performance. International Small Business Journal, 27(1), 39-69. 
Tate, W. L., Ellram, L. M., \& Dooley, K. J. (2014). The impact of transaction costs and institutional pressure on supplier environmental practices. International Journal of Physical Distribution \& Logistics Management, 44(5), 353-372. http://dx.doi.org/10.1108/IJPDLM-12-2012-0356

The Chartered Institute of Procurement and Supply. (2012). Sourcing in Procurement and Supply. UK: Profex Publishing Limited.

Vickery, S. K., Jayaram, J., Droge, C., \& Calantone, R. (2003). The effects of an integrative supply chain strategy on customer service and financial performance: An analysis of direct versus indirect relationships. Journal of Operations Management, 21, 523-539. http://dx.doi.org/10.1016/j.jom.2003.02.002

Williamson, O. E. (1979). Transaction-Cost Economics: The Governance of Contractual Relations. Journal of Law and Economics, 22, 233-261. Retrieved from http://www.jstor.org/stable/725118

Williamson, O. E. (2008). Outsourcing Transaction Cost Economics and supply chain management. Journal of Supply Chain Management, 44(2), 5-16. http://dx.doi.org/10.1111/j.1745-493X.2008.00051.x

Zhang, J., \& Keh, T. H. (2009). Interorganisational exchanges in China: Organisational forms and governance

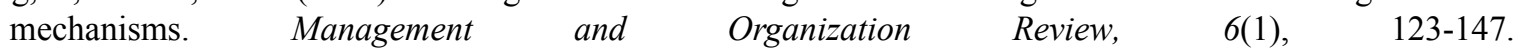
http://dx.doi.org/10.1111/j.1740-8784.2009.00148.x

Zhang, W., Fu, J., Li, H., \& Xu, W. (2012). Coordination of supply chain with a revenue-sharing contract under demand disruptions when retailers compete. International Journal of Production Economics, 138(1), 68-75.

Zheng, J., Roehrich, J. K., \& Lewis, M. (2008). The dynamics of contractual and relational governance: Evidence from long-term public-private procurement arrangements. Journal of Purchasing and Supply Management, 14(1), 43-54. http://dx.doi.org/10.1016/j.pursup.2008.01.004

\section{Copyrights}

Copyright for this article is retained by the author(s), with first publication rights granted to the journal.

This is an open-access article distributed under the terms and conditions of the Creative Commons Attribution license (http://creativecommons.org/licenses/by/3.0/). 